\title{
Zooplankton of Oman Coastal Waters
}

\author{
Sergey A. Piontkovski ${ }^{*}$, Asila Al-Maawali², Ward Al-Muna Al-Manthri ${ }^{1}$, \\ Khalid Al-Hashmi ${ }^{1}$, and Elena A. Popova ${ }^{3}$ \\ ${ }^{1}$ College of Agricultural and Marine Sciences, Sultan Qaboos University, \\ P.O. Box 34, Al-Khod 123, Sultanate of Oman \\ ${ }^{2}$ Marine Science Fisheries Centre, Ministry of Agriculture and Fisheries Wealth, \\ P.O. Box 227, Sultanate of Oman \\ ${ }^{3}$ Institute of Biology of the Southern Seas, 2 Nakhmov av.-Crimea \\ 99011, Sevastopol, Ukraine
}

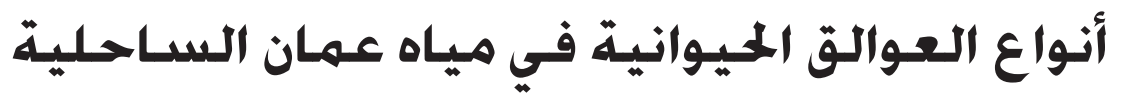

سـيرجي أ بيونتكـوفسـكي وأصيلة المعولي وورد المنسى المنذريـة وخـالد الهـاشسمي و إلينـا بوبـوفا

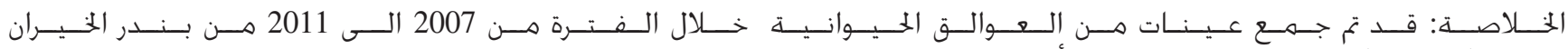
(23.51º N, 58.72º E)

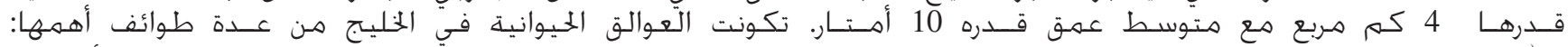
(7\%)Oikopleuriddae, (9\%)Cladocera, (Decapoda ( 2\%) Chaetognatha (3\%) ,

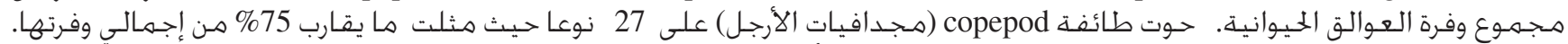

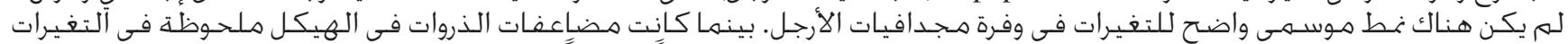

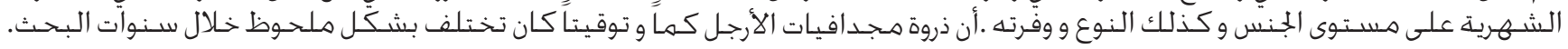

$$
\text { كلمات مفتاحية: مهـدافيات ، العوالق الخيوانيـة بحر العـرب }
$$

\begin{abstract}
Monthly sampling during daytime was carried out in 2007-2011 at Bandar Al-Khyran $\left(23.51^{\circ} \mathrm{N}, 58.72^{\circ} \mathrm{E}\right)$ which is the largest semi-enclosed bay on the southern end of the Sea of Oman with about $4 \mathrm{~km}^{2}$ in surface area and an average depth of $10 \mathrm{~m}$. Zooplankton were represented by Copepoda (79\%), Cladocera (9\%), Oikopleuriddae (7\%), Chaetognatha (3\%), and Decapoda ( 2\%) comprising the major part of the total zooplankton abundance. Among copepods, 27 species constituted $\sim 75 \%$ of total copepod abundance. Changes of copepod abundance have not had a pronounced seasonal pattern. Instead, a multiple peak structure in monthly fluctuations was observed, on the level of genera as well as the abundance of species. Amplitudes and timing of the copepod peak abundance were markedly different during the studied years.
\end{abstract}

Keywords: Copepods, zooplankton, the Arabian Sea.

\section{Introduction}

The necessity to study zooplankton stems from the important role this group of organisms play in the structure and functioning of Omani coastal ecosystems. On one hand, zooplankton species are the consumers of phytoplankton; that means the consumers of the algal blooms as well. At the early stage of algal bloom development, due to intensive grazing, copepods are able to modify the food web structure and shift the phytoplankton species composition (Tan et al., 2004). On the other hand, zooplankton organisms contribute to the food spectrum of pelagic predators. Epipelagic and mesopelagic fish are a marked part of fish-kill incidents reported along the Omani coast (Al-Gheilani et al., 2005; Tangaraja et al., 1997).
Coordinated zooplankton studies of the north-western part of Arabian Sea began in the 1970s, during the time of the International Indian Ocean Expedition (Panikkar and Rao, 1973). In the 1990s, a series of research cruises with zooplankton sampling were carried out by the Former Soviet Union expeditions (Banse and Piontkovski, 2006), the Netherlands NIOP program (Baars, 1994), the UK ARABESQUE program (Burkill, 1999), the Pakistani NASSER program (Kidwai and Amjad, 2000), and the International JGOFS program (Smith et al., 1998). These studies dealt predominantly with the oceanic and upwelling regions.

The first extended zooplankton sampling in Omani coastal waters was carried out onboard the R/V "Fridtjof 
Nansen", in March to June 1976 (Anonymous, 1975). Materials of these sampling were analyzed later by K.V. Jayalakshmy (2000), who reported the latitudinal variation in the abundance, diversity, dominance, and zonation of the major groups of zooplankton.

In the Sea of Oman, regular (seasonal) sampling of zooplankton in coastal waters was initiated by the Ministry of Fisheries in 1990 and it continues up to the present time. The materials highlighting these sampling are available in the form of annual reports (Thangaraja 1990, 1991). In these studies featuring coastal waters, zooplankton were analyzed to the level of taxonomic groups (Chaetognaths, Decapods, Copepods, Ostracods, and etc.) with no detailed studies on species. The species level is important because within a taxonomic group, species could occupy different ecological niches (being the herbivores, carnivores, or omnivores).

With this regard, our goal was to study the taxonomic diversity of zooplankton in the coastal waters of the Sea of Oman, to evaluate dominant species, and to understand seasonal changes of zooplankton abundance.

\section{Methods}

Monthly sampling during daytime was carried out in $2007-$ 2011 at Bandar Al-Khyran $\left(23.51^{\circ} \mathrm{N}, 58.72^{\circ} \mathrm{E}\right)$ which is the largest semi-enclosed bay on the southern end of the Sea of Oman, with about $4 \mathrm{~km}^{2}$ in surface area and an average depth of $10 \mathrm{~m}$. The bay has two inlets and is surrounded by steep rocky hills and cliffs of Permian limestones and shales lined with shallow coral communities.

Zooplankton samples were collected using a Bongo net (mouth surface area: $0.125 \mathrm{~m}^{2}$ ), with a $150 \mu \mathrm{m}$ mesh size sieve equipped with a "Hydrobios" digital flowmeter. The net was towed obliquely at a speed of one knot from near the bottom to the surface.

Samples were transferred to $0.5 \mathrm{~L}$ bottles and preserved in $5 \%$ borate-buffered formaldehyde for later analysis. In the laboratory, the organisms encountered were identified to the genus level and if possible to species level and then counted under a stereomicroscope after sub-sampling.

\section{Results}

Zooplankton was represented by several taxonomic groups - Copepoda (79\%), Cladocera (9\%), Oikopleuriddae (7\%), Chaetognatha (3\%), and Decapoda ( 2\%) comprising the major part of the total zooplankton abundance. Copepods were the most abundant group contributing 80\%, of which 27 species constituted $\sim 75 \%$ of total copepod abundance (Table 1).

Seasonal changes of the total copepod abundance exhibited a peak in September in 2007, 2009, and 2010 (Fig. 1). In 2010, the total copepod abundance had a peak in February, which was more pronounced that the peak in September. Zooplankton sampling in 2008 was not regular, however two peaks- in February and June were noticed. In 2011, the fall peak observed in 2007-2010, was shifted to November.
Table 1. Characteriostic species of copepods of the Bandar AlKhyran Bay.

\begin{tabular}{|c|c|c|}
\hline Copepod Species & $\begin{array}{l}\text { Abundance } \\
\text { (ind } \mathrm{m}^{-3} \text { ) }\end{array}$ & $\begin{array}{c}\text { Total } \\
\text { Copepod } \\
\text { Abundance } \\
(\%)\end{array}$ \\
\hline Oithona brevicornis & 1511184 & 9.7 \\
\hline Oithona spp. & 1483726 & 9.5 \\
\hline Temora turbinata & 1394334 & 9.0 \\
\hline Oncaeidae & 1231872 & 7.9 \\
\hline Oithona nana & 1190109 & 7.6 \\
\hline Parvocalanus elegans & 940415 & 6.0 \\
\hline Oithona simplex & 695603 & 4.5 \\
\hline Microsetella spp. & 575797 & 3.7 \\
\hline Euterpina acutifrons & 506760 & 3.3 \\
\hline Acrocalanus spp. & 309102 & 2.0 \\
\hline Acartia amboinensis & 200816 & 1.3 \\
\hline Corycaeus spp. & 199764 & 1.3 \\
\hline Paracalanus indicus & 168841 & 1.1 \\
\hline Acartia spp. & 163440 & 1.0 \\
\hline Paracalanus spp. & 150059 & 1.0 \\
\hline Centropages orsinii & 121376 & 0.8 \\
\hline Paracalanus denudatus & 101083 & 0.6 \\
\hline Oncaea clevei & 100686 & 0.6 \\
\hline Temora spp. & 94177 & 0.6 \\
\hline Parvocalanus spp. & 86924 & 0.6 \\
\hline Oithona plumifera & 82915 & 0.5 \\
\hline Paracalanus aculeatus & 82593 & 0.5 \\
\hline Subeucalanus pileatus & 80147 & 0.5 \\
\hline $\begin{array}{l}\text { Parvocalanus } \\
\text { crassirostris }\end{array}$ & 69346 & 0.4 \\
\hline Acrocalanus longicornis & 67667 & 0.4 \\
\hline Centropages spp. & 47410 & 0.3 \\
\hline Paracalanus tropicus & 41230 & 0.3 \\
\hline
\end{tabular}

In analyzing monthly changes of copepod abundance to the level of genera and species, a multiple peak dynamic was noticed (Figs. 2 and 3). For Oncaeidae for instance, over the 5 years of zooplankton sampling, peaks were pronounced in September, and November in 2007. The situation was different in 2008 , when a major peak was observed in June. In 2009, only one peak was observed in September. In 2010, only one peak was recorded in February. 


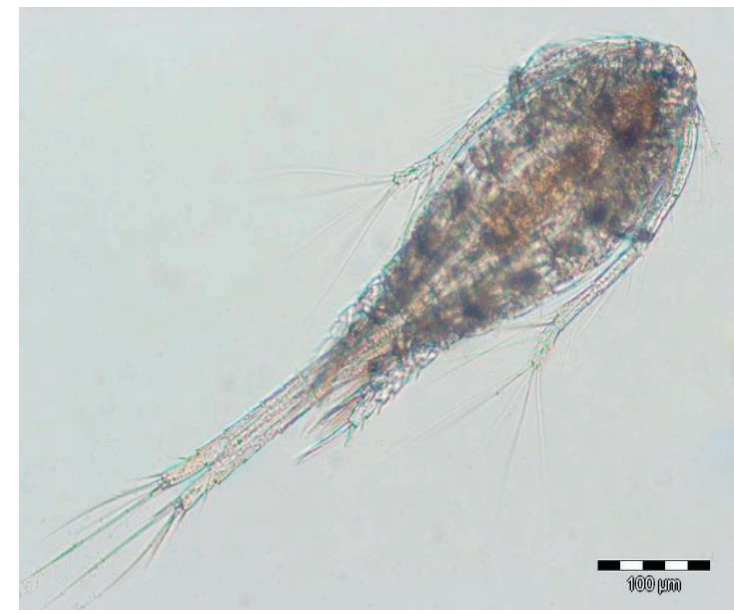

Oithona sp. (o)

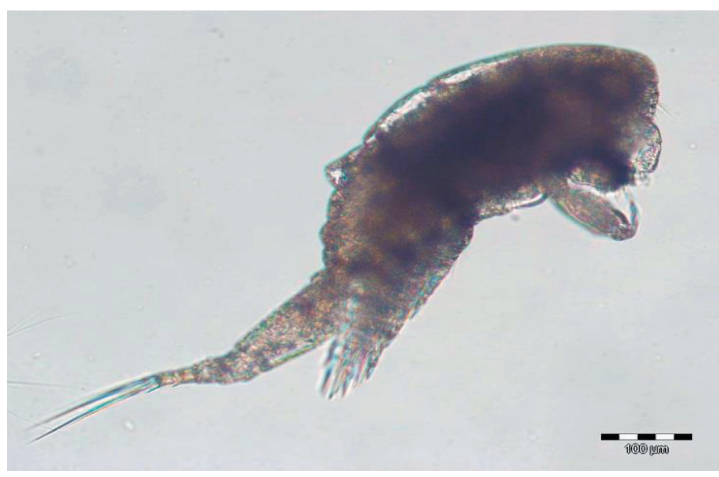

Oncaea sp. (오)

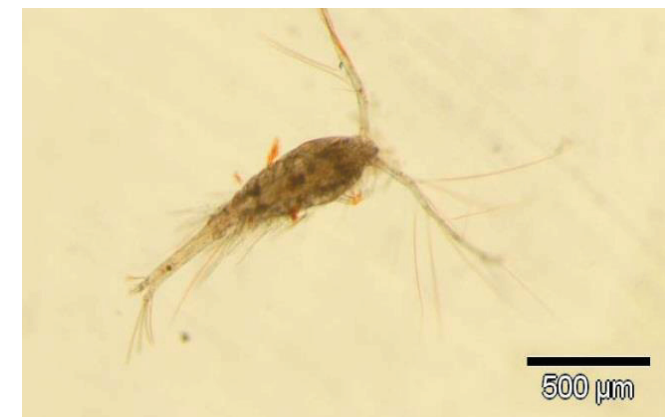

Oithona plumifera 'ㅇ)

Acartia sp. (ठ)

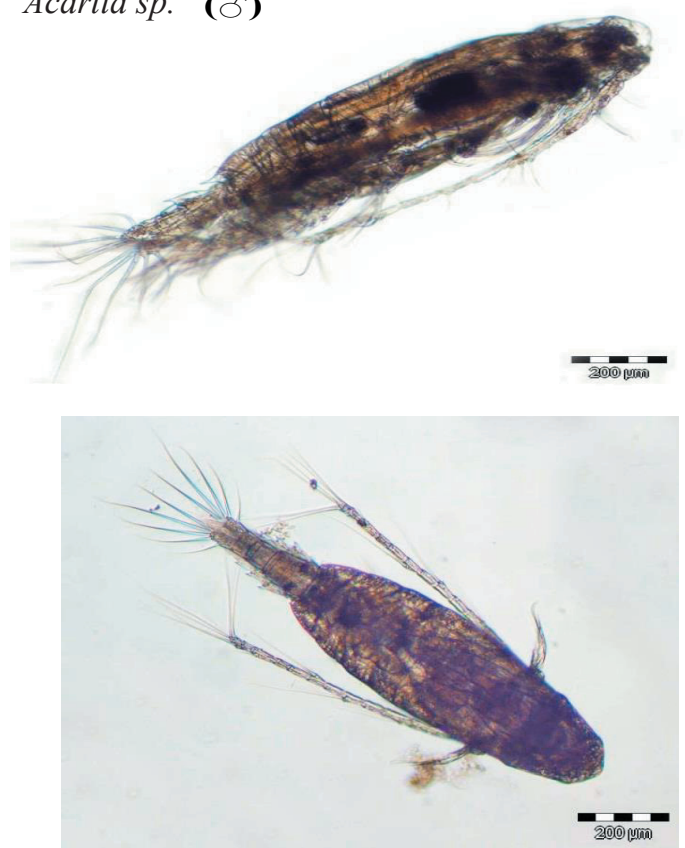

Acartia sp. (우)

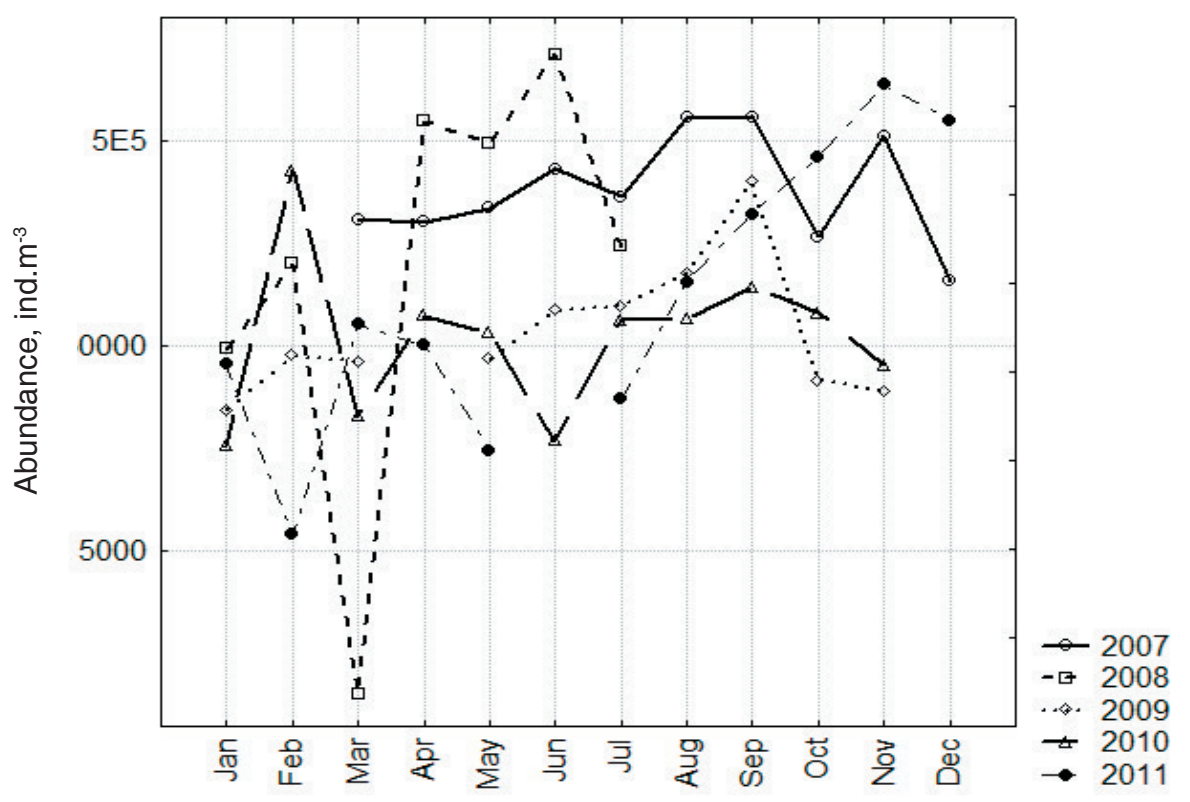

Figure 1. Photographs of some copepod species identified in samples and seasonal changes of the total copepod abundance over years. The Y-axis has the logarithmic scale. 


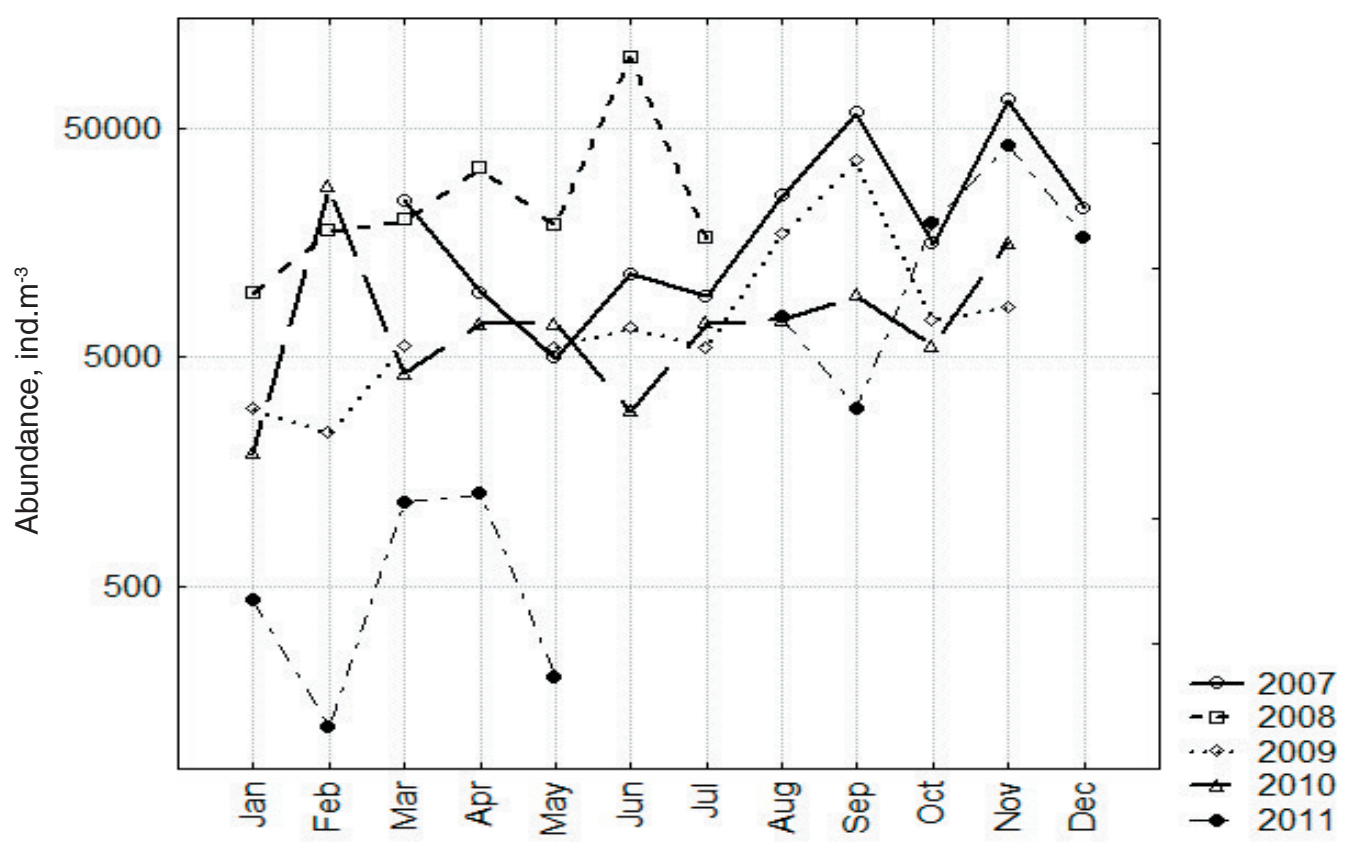

Figure 2. Seasonal changes of the total abundance of Oncaeidae species.

For the other groups and species, the multiple peak structure was pronounced as well; peaks varied by timing and amplitudes (Fig. 3).

In terms of interannual changes, it was noticed that the year 2008 was quite different compared to the other three years of sampling. This was the year of maximal amplitudes for almost all the species and genera. Also, a gradual shift in taxonomic structure of the plankton community was reported; coastal waters were invaded by the dinoflagellate Cochlodinium polykrikoides which was the dominant species of phytoplankton, and caused a huge bloom and massive fish kills in Omani coastal waters (Matsuoka et al., 2011; Richlen et al., 2010).

Interannual changes as well as seasonal patterns might be markedly different even for the species of the same genus. We exemplified that fact by the seasonal cycles of 6 species from genus Oithona (Fig. 4). This genus is believed to be one of the most important and dominant in the World's Ocean (Gallienne and Robins, 2001). Obviously, timing and amplitudes of abundance are quite variable over the four sampled years and they are far from being similar from species to species.

What unites all these species however is an extremely high variability ranging from a few individuals per cubic meter to hundred thousands of individuals of the same species per cubic meter a few months later.

In comparison to the other taxonomic groups, Copepoda is not only the most dominant in terms of contribution to the total zooplankton abundance, but the most variable as well. During the seasonal cycle, many species (like Oithona brevicornis and Temora turbinata) could reach a concentration of millions of individuals per cubic meter but exhibit a gradual reduction (up to hundreds of individuals) a couple of months later. The other species (like Subeucalanus pileatus and Paracalanus tropicus) whose concentration reaches thousands of individuals per cubic meter, could disappear from the community completely in a few months.

In order to understand the role the species play in the formation of the total variance of the copepod community, Principal Component Analysis was carried out (Table 2). In the analysis, the Varimax normalized correlation matrix was employed.

The factor loadings implied that Factors 1, 2, and 3 explain $36 \%, 30 \%$, and $14 \%$ of the total variance correspondently. The cumulative variance explained by these 3 factors was $80 \%$. In table 2 , values with a statistically significant contribution to a factor loading are given in bold. Obviously, species tend to form a certain group mostly contributing to the variance. In Factor 1, the components (species) of such a group are quite diverse, whereas in Factor 2, the dominant group is formed mostly by the Oithona species.

As for the seasonal changes of the other taxonomic groups, the later ones exhibit a multiple of peaks, shifting over years. For instance in the dynamics of Chaetognatha, all five years are different by amplitudes and timing (Fig. 5).

The same goes for the monthly fluctuations of the Decapoda larvae (Fig. 6). All five years might be named the years of markedly different fluctuations of abundance exhibiting multiple peaks. Some of them are matched by timing (in May and September), while the others are not. 

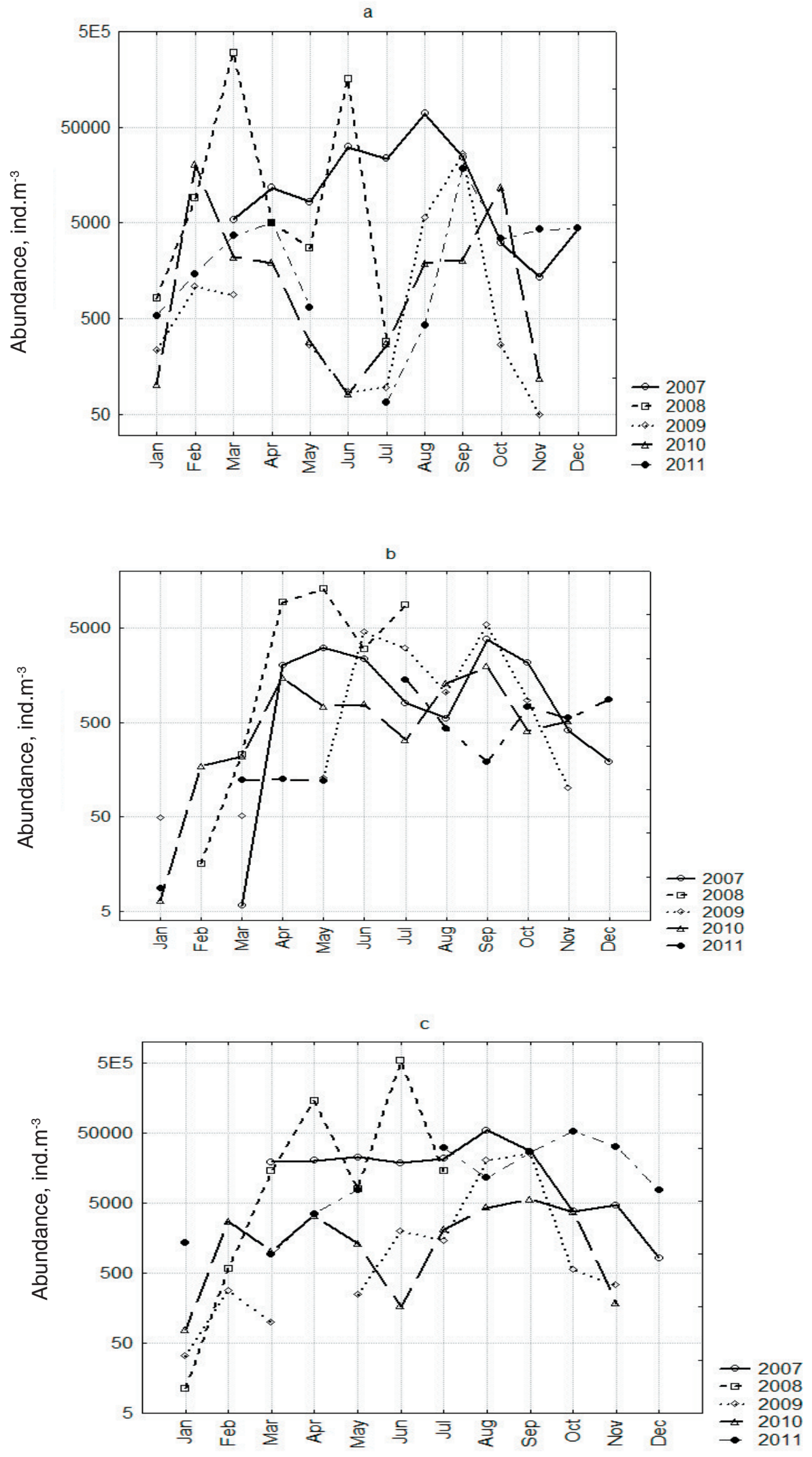

Figure 3. Seasonal changes of the abundance of some typical species (a) Temora turbinata, (b) Centropages orsinii, and (c) Penilia avirostris. 
Table 2. Results of the Principal Component Analysis. Factor loadings for the copepod community.

\begin{tabular}{lccc}
\hline Species & Factor 1 & Factor 2 & Factor 3 \\
\hline Oithona brevicornis & 0.10 & 0.86 & 0.32 \\
Oithona spp. & 0.29 & 0.88 & 0.18 \\
Temora turbinata & 0.27 & 0.84 & 0.20 \\
Oncaidae & 0.76 & 0.35 & 0.40 \\
Oithona nana & 0.47 & 0.69 & 0.39 \\
Parvocalanus elegans & 0.29 & 0.66 & 0.31 \\
Oithona simplex & 0.44 & 0.78 & 0.10 \\
Euterpina acutifrons & 0.62 & 0.58 & 0.21 \\
Acrocalanus spp. & 0.82 & 0.38 & 0.00 \\
Acartia amboinensis & 0.27 & 0.32 & 0.84 \\
Corycaeus spp. & 0.67 & 0.49 & 0.30 \\
Paracalanus indicus & 0.69 & 0.44 & 0.28 \\
Paracalanus spp. & 0.68 & 0.48 & 0.13 \\
Centropages orsinii & 0.00 & 0.48 & 0.78 \\
Oncaea clevei & 0.79 & -0.16 & 0.45 \\
Parvocalanus spp. & 0.53 & 0.69 & 0.09 \\
Oithona plumifera & 0.82 & 0.39 & 0.19 \\
Paracalanus aculeatus & 0.90 & 0.22 & 0.20 \\
Subeucalanus pileatus & 0.62 & 0.48 & 0.17 \\
Parvocalanus & 0.66 & 0.31 & -0.17 \\
crassirostris & 0.66 & 0.13 & 0.61 \\
Acrocalanus longicornis & 0.66 & 0.51 & 0.45 \\
Paracalanus tropicus & & & \\
\hline
\end{tabular}

In terms of trophic interactions, a multiple peak structure in the dynamics of zooplankton abundance a priori sets up the situation when, 1) zooplankton abundance will be synchronized with monthly changes of food objects (the abundance of phytoplankton organisms); 2) zooplankton and phytoplankton abundance exhibit contra-phased fluctuations; and 3) zooplankton and phytoplankton abundance exhibit lagged-in time (but related) fluctuations.

In order to compare fluctuations of zooplankton and phytoplankton, we analyzed monthly changes of the abundance of two major groups - diatoms and dinoflagellates (Fig. 7).

In this plot, monthly time series of abundance were subjected to logarithmic transformations and represented in the form of deviations from the mean. Seasonal changes of phytoplankton abundance have demonstrated (more clearly than zooplankton groups) a certain relationship with the monsoon seasons. Overall, $69 \%$ of the diatom peaks (positive deviations from the mean) and $64 \%$ of the dinoflagellate peaks both matched the time of summer or winter monsoons. Diatoms formed peaks predominantly during winter, whereas the dinoflagellate peaks were most frequent during summer time. A detailed description of the phytoplankton seasonal changes might be found in AlHashmi et al. (2012).

As for interannual changes, the duration of time series allowed us to analyze this issue in general terms only. For instance in 2010, peaks of diatoms and dinoflagellates were less pronounced and the mean abundance was low compared to the previous three years. Hopefully, a posterior sampling will allow us to resemble interannual trends with a sufficient accuracy.

Phytoplankton and zooplankton organisms are supposed to be actively consumed by epipelagic fish populations. In Omani coastal waters for instance, sardines (comprising about 50\% of annual fish landing) are planktivorous species. In the Sea of Oman, the sardine fishery has not been changing much, in the sense of fishing gear used and fishing boats involved (Fishery Statistics Book, 2011). In following Longhurst and Wooster (1990) and George et al. (2012), we hypothesized that in those kinds of situations, the sardine landings are representative of stock abundance. In this regard, sardine landings and data on zooplankton abundance both might be interpreted in the light of predator-prey interactions.

The monitoring of sardine landings along the Omani coast, carried out by the Ministry of Agriculture and Fisheries, from 1970s through the present time, has resulted in historical data with the most detailed data available for the Muscat region (Fig. 8) (Fisheries Statistics Book, 20011). We selected the data covering years of zooplankton sampling (from 2007 to 2011). Monthly time series demonstrated peaks of landings of which $63 \%$ corresponded to the time of the winter monsoon. In zooplankton dynamics, December and January were the months of low abundance of copepods, as well as some other zooplankton groups (Figs. 1, 5, and 6).

\section{Discussion}

An interesting geographical feature of the Omani coast is the difference in modes of ocean-atmosphere interaction. The Sea of Oman is mainly affected by the Northeast (winter) Monsoon, whereas the coast overlooking the Arabian Sea (in particular, the southern part of this coast) is mediated by the Northeast and Southwest Monsoons. The result is markedly different seasonal cycles of plankton communities inhabiting coastal waters of these regions.

In the surface waters of the Arabian Sea, inhabited by about 50 species of copepods, approximately 11 species dominate throughout the annual cycle (Madhupratap et al., 1992; Timonin, 1971). In the Sea of Oman, the total number of species was higher and the dominant group of species was wider. Out of 140 species encountered, 27 species comprised $75 \%$ to the total copepod abundance.

The dominance of small-sized copepods of genus Oithona, Temora, Oncaea, Parvocalanus, Paracalanus, Microsetella, Acartia and some others was a typical 

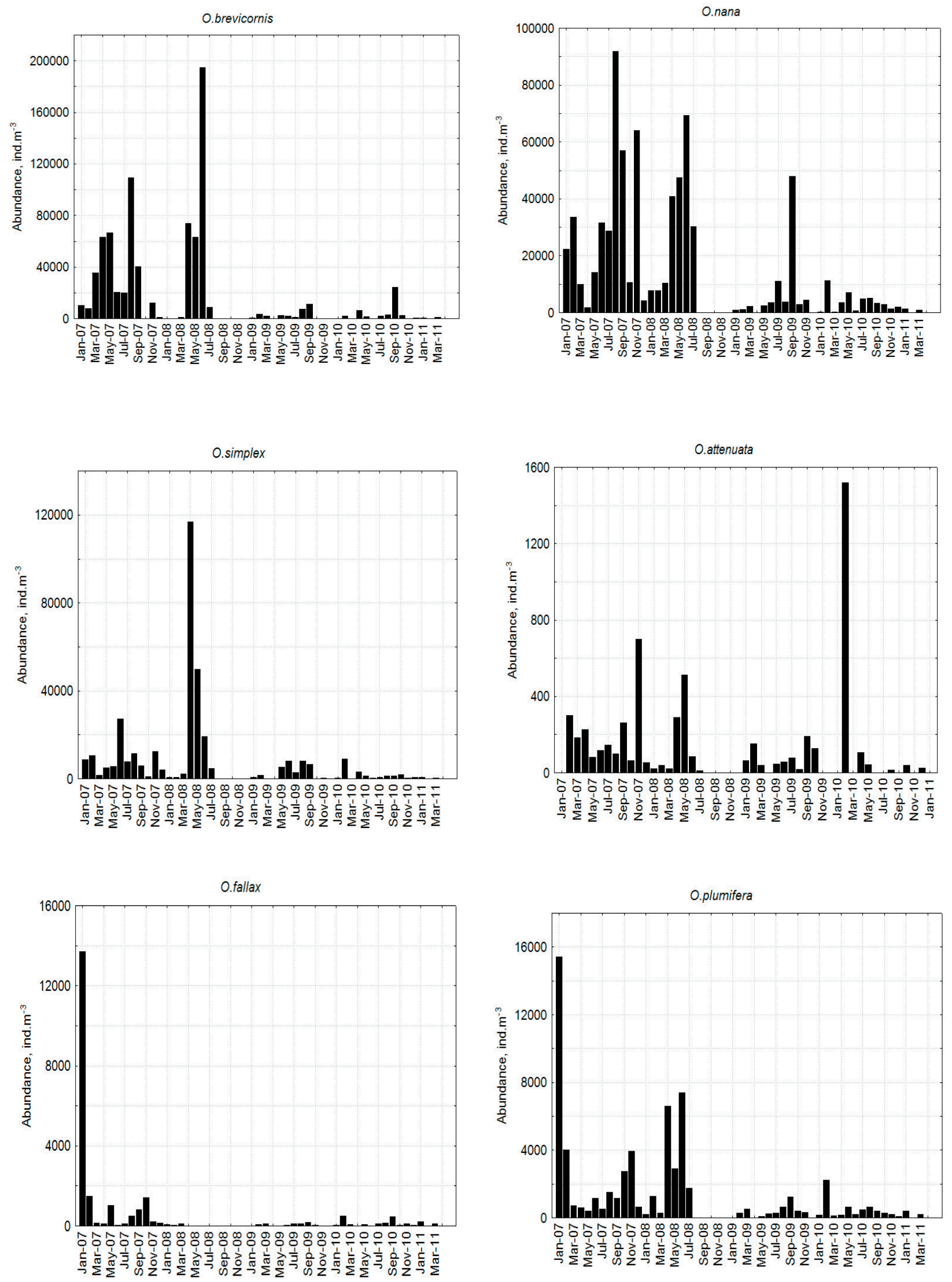

Figure 4. Seasonal changes of species abundance: genus Oithona. 


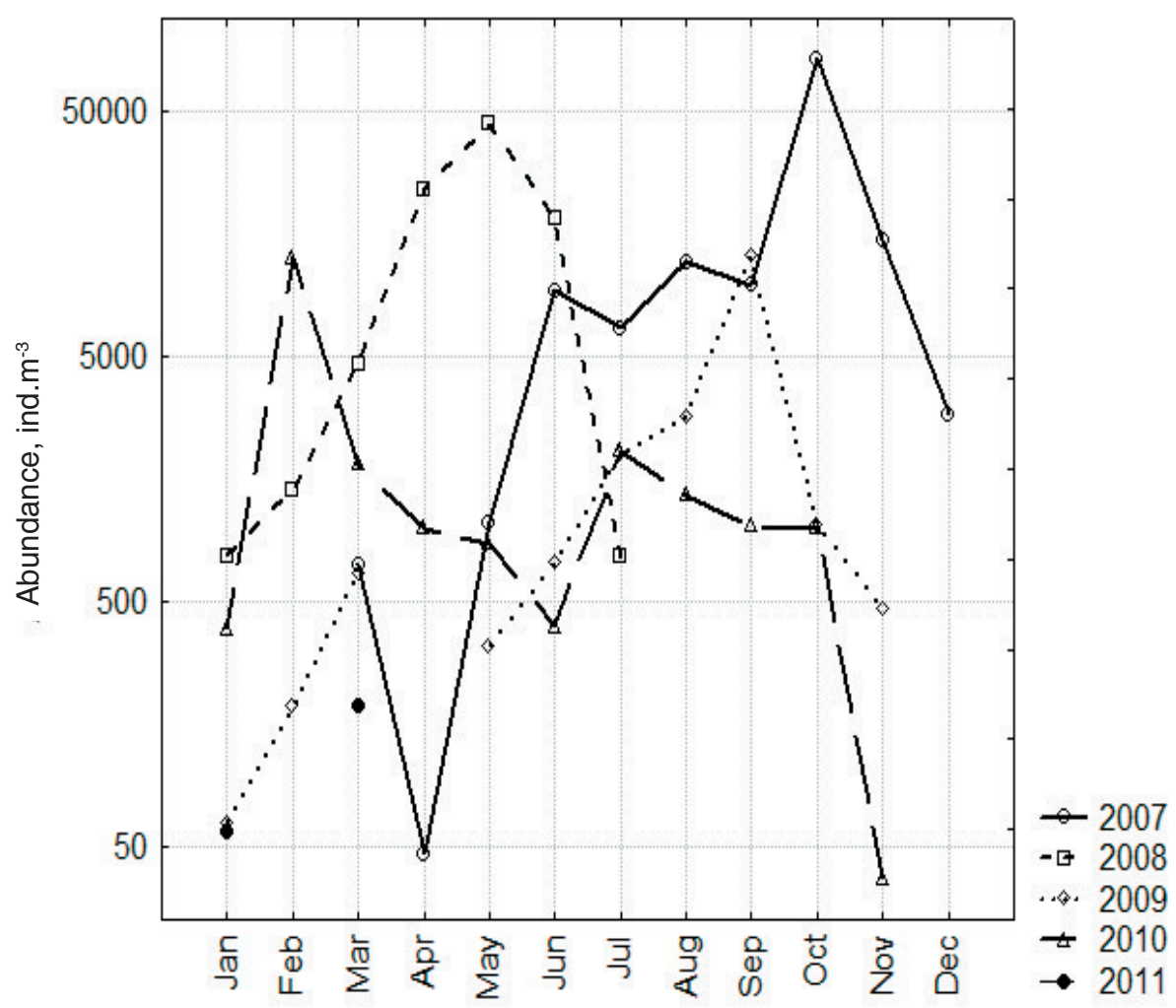

Figure 5. Seasonal changes of the Chaetognatha abundance.

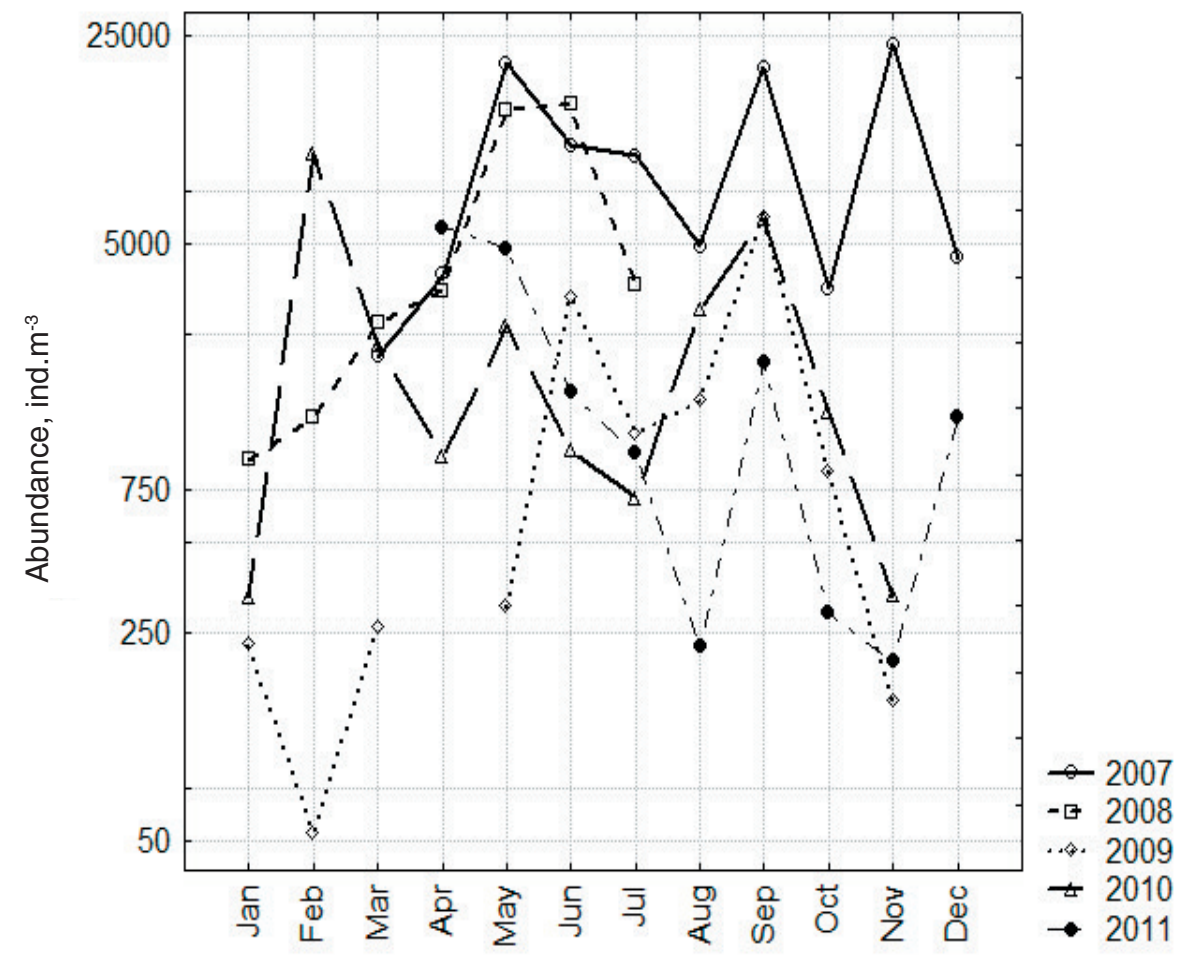

Figure 6. Seasonal changes of the Decapoda abundance. 

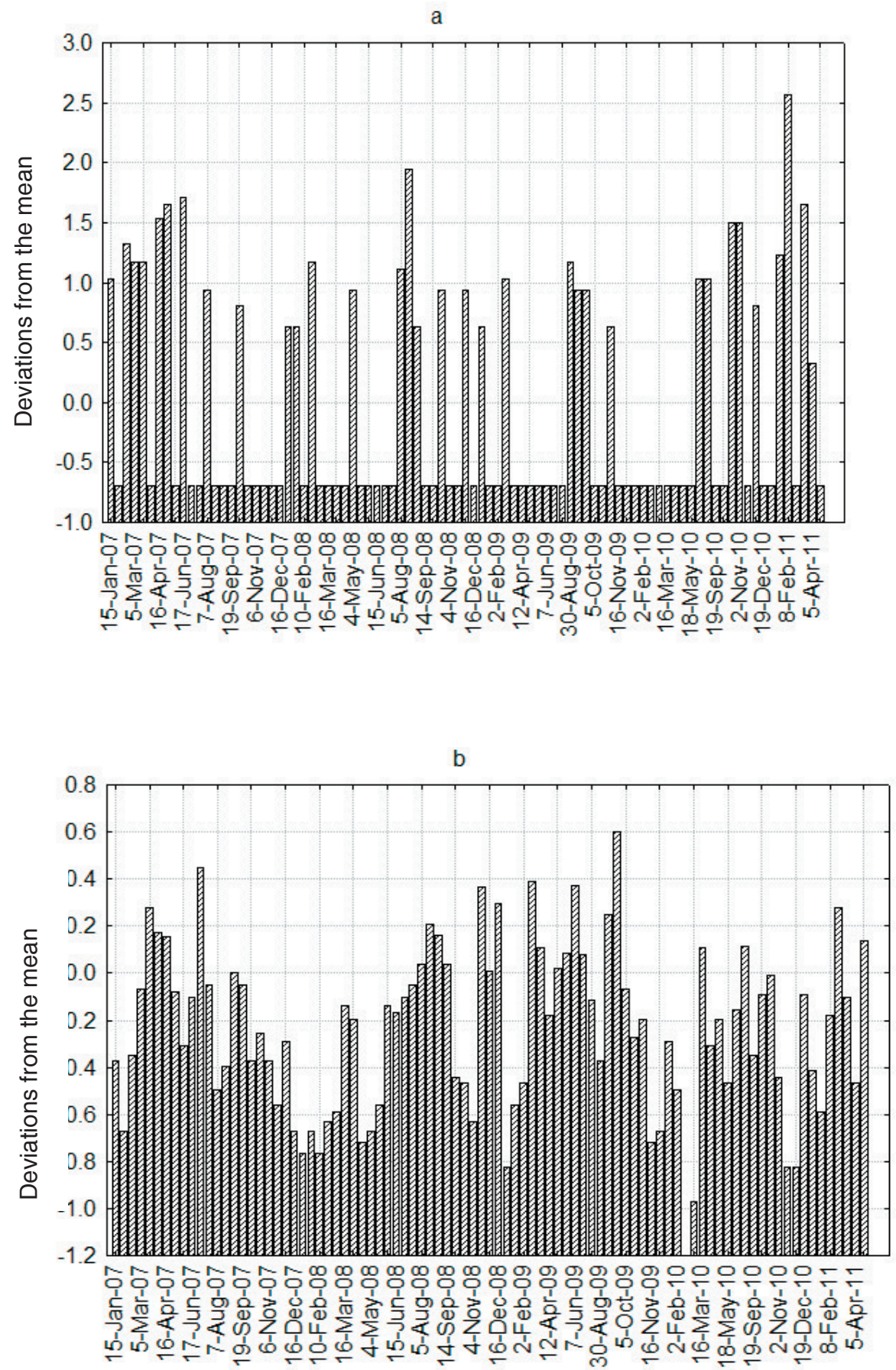

Figure 7. Monthly changes (deviations from the mean) of (a) diatom abundance and (b) dinoflagellate abundance. 


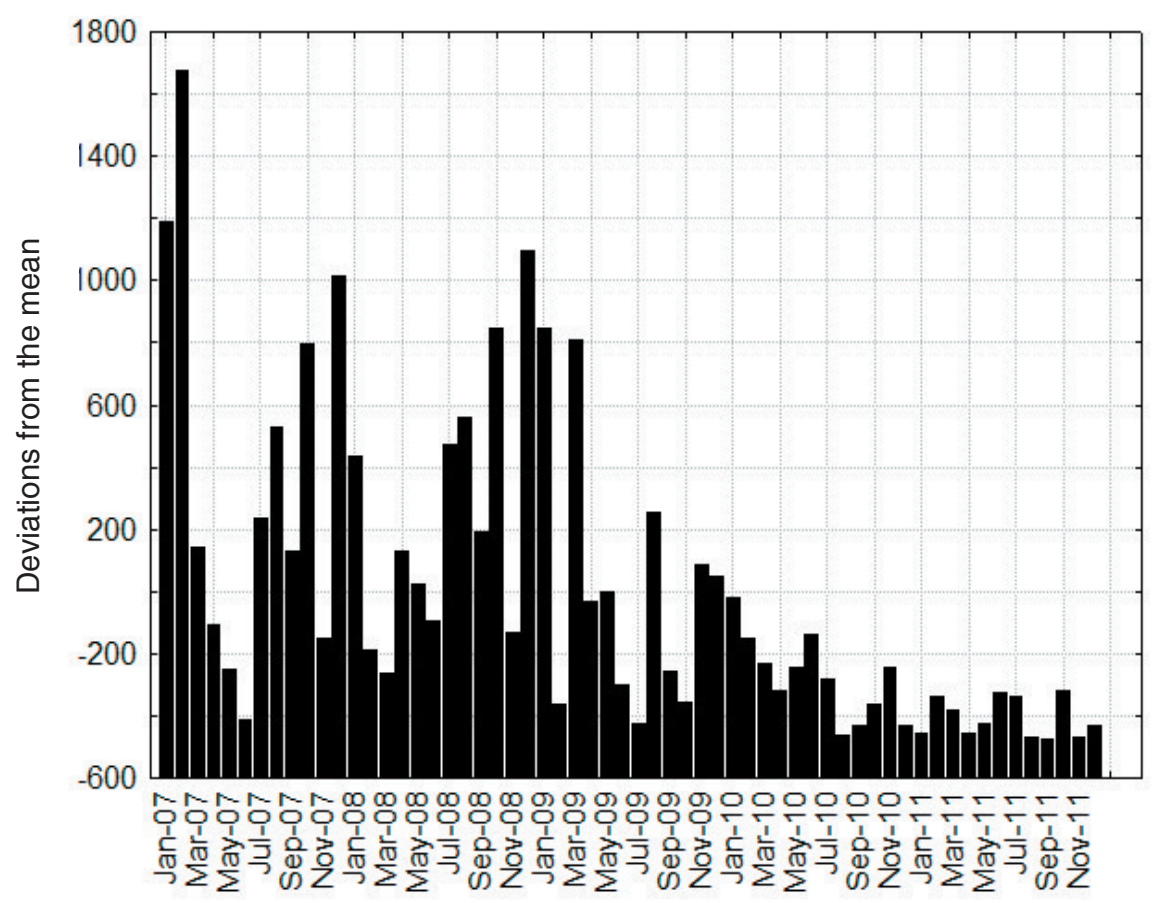

Figure 8. Seasonal changes of sardine landings (Muscat region).

feature of the plankton community inhabiting coastal waters of the Sea of Oman. Moreover, similar genera (Oncaea, Paracalanus, and Acartia) were reported far to the south down the coast- in Ras Madrakah and Ras Marbat regions, in which sampling off the coast was carried out by the US GLOBEC expedition (Hitchcock et al., 2002). For instance, at Ras Marbat, the dominant taxa were small-bodied Acartia spp., Corycaeus spp., Oncaea spp. and Paracalanus spp. in both daytime and night-time tows. At Ras Fartak (which is about $200 \mathrm{~km}$ to the south), copepods were dominated by Paracalanus spp.

If we expanded our comparison towards the waters of the Arabian Gulf, a similar tendency would be noticed there as well. The dominant copepod genera are: Oithona, Oncaea, and Paracalanus (Al-Khabbaz and Fahmi, 1998; Al-Yamani et al., 1998). Consequently, small-sized copepod species dominate coastal waters of the western Arabian Sea and the Gulf. In oceanic waters of the Arabian Sea, zooplankton biomass is dominated by largesized copepods $>2 \mathrm{~mm}$ (Roman et al., 2000).

Interestingly, studies similar to ours were conducted on the northern (Iranian) coast of the Sea of Oman, across the Muscat region, from August to November 2007 and from February to May 2008 (Fazeli et al., 2010). The authors identified 75 copepod species and demonstrated that Copepoda was the dominant group throughout the seasons and that zooplankton abundance in the region follows a cycle related to the monsoonal winds. Along with that, their study revealed a correlation between copepod abundance, chlorophyll- $a$, and concentration of phosphates. A time lag between copepod abundance and chlorophyll was noticed.

A multiple peak structure of the abundance reported for species and genera (Figures 1-4), reflects the adaptation of zooplankton populations to availability of food on one hand and to the press of predators (carnivorous zooplankton and mesopelagic fish) on the other. Multiple peaks do also imply that there is no well-pronounced seasonal pattern. Lack of seasonality in copepod abundance has been reported before, for the central and eastern Arabian Sea (Mahupratap et al., 1996).

Nonetheless, it was demonstrated that the Northeast Monsoon season "is always characterized by an increase in the abundance of the cyclopoid copepods, particularly Oithona species, regardless of location in the Arabian Sea" (Smith and Madhupratap, 2005). We tested this concept's applicably to the coastal community of Omani waters. It was found that the Oithona species did not exhibit this pattern (Figure 4). All 6 abundant species have had different seasonal changes over the years and the majority of the peaks observed did not match the time of the Northeast Monsoon.

Smith et al. (1998b) have reported that in the western Arabian Sea, the most abundant copepod species of the upper $25 \mathrm{~m}$ in the upwelling area during the Southwest Monsoon were the small-bodied Paracalanus aculeatus, Paracalanus denudatus and Parvocalanus dubia (Smith et al., 1998b). Four species of copepod (P. denudatus, P. dubia, P. aculeatus and Acartia longicornis) account for $36 \%$ of the total numbers in the upper $25 \mathrm{~m}$ during 
the Southwest Monsoon. With two other species added (Subeucalanus crassus and Calanoides carinatus), the group will account for $37 \%$ of total abundance (Smith and Madhupratap, 2005).

In our case, the group accounting for $37 \%$ of total abundance was different (Table 1). Overall, this means that species composition of abundant species in the Sea of Oman versus the western Arabian Sea is different, and seasonal cycles of species inhabiting shallow coastal waters of the Sea of Oman might not match seasonal cycles of the same species or genera inhabiting shelf and oceanic waters of the western Arabian Sea.

As far as the grazing patterns are concerned, the small-sized copepods inhabiting coastal waters are the herbivores, omnivores, and carnivores so the feeding strategy of many of them is quite diverse. Depending on food availability, one and the same species could switch feeding behavior from herbivores to omnivores or carnivores. For instance, both phytoplankton and zooplankton remains were frequently found in the guts of Oncaea species (Pasternak 1984; Turner, 1986; Hopkins 1987). In the oligotrophic Red Sea, this species actively consume appendicularian houses (Ohtsuka et al., 1996). Lampitt et al. (1993) reported Oncaea conifera consuming amorphous marine snow. In experiments, Temora longicornis actively consumed diatoms (Yule and Crisp, 1983), as well as ciliates (Jakobsen, 2005), and fecal pellets (Poulsen and Kiørboe, 2005).

In the sub-arctic waters of the White Sea, three species of copepods (Acartia spp., Centropages hamatus and Temora longicornis) consume up to $85 \%$ of phytoplankton standing stock (in terms of chlorophyll- $a$ ), and play a significant role in the transformation of particulate organic matter (Martynova et al., 2011).

The cyclopoid family Oithonida is one of the most abundant groups inhabiting coastal waters worldwide (Paffenhöfer 1993, Gallienne and Robins, 2001). This group combines a feeding strategy that includes consumption of herbivores, carnivores, and omnivores (Drits and Semenova, 1984; Nishibe et al., 2010; Uchima and Hirano, 1986).

Feeding of the Oncaea species is poorly understood. In coastal waters, they were found attached to large zooplankton organisms such as Salpa spp, Sagitta spp., and Oikopleura spp (Go et al., 1996). Copepod nauplii, copepodits, diatoms, and appendicularia houses were found in the guts of large-sized species and rarely in small-sized onesof less than $0.7 \mathrm{~mm}$ in length (Ohtsuka et al., 1996).

Gut contents of 3 copepods including Oncaea venusta, $O$. mediterranea, and O. conifera, of the southern Taiwan Strait were picked out using a fine needle under a stereomicroscope and then examined with scanning electron microscopy. Study of the gut content showed that the major components of their diets were the diatoms Chaetoceros sp. and Thalassiothrix sp. Along with that, radiolarian, microzooplanktonic, and copepod debris was also found in the gut contents (Wu et al., 2004).
Among the other groups markedly contributing to the total zooplankton abundance of Omani coastal waters, Penilia avirostris (Cladocera) was noticed. This species is a typical inhabitant of neritic waters reported all over the globe. The diet of Penilia is flexible, ranging from small diatoms and bacterivorous microflagellates (Turner et al., 1988) to prymnesiophyceans (Paffenhöfer and Orcutt 1986) and bacteria (Lipej et al., 1997). Katechakis and Stibor (2004) reported significant grazing on elongated diatoms (Nitzschia elongata and Rhizosolenia spp) or long-chain diatoms (Skeletonema costatum and Thalassiosira spp.) up to $135 \mu \mathrm{m}$ long.

Recent studies in the Gulf of Trieste (Adriatic Sea) showed that in summer-2000, P. avirostris was preferentially consuming diatoms, and particularly the elongated cells of Proboscia (Rhizosolenia) alata (2.5-13 $\mu \mathrm{m})$. In summer- 2002, this species fed upon autotrophic nanoplankton. $P$. avirostris grazed also on microzooplankton- mostly small ciliates and heterotrophic dinoflagellates. (Fonda-Umani et al., 2005).

The above comparisons imply that all the discussed species or genera of zooplankton reported for the Omani coastal waters possess a flexible feeding strategy and might be active consumers of algal blooms. The percentage of the phytoplankton standing stock ingested is yet to be estimated however. The assessment carried out for the other geographical regions implies a marked variety- from non-significant effects not exceeding a few percent (Calbet et al., 2009; Dame et al., 1993) to a gradual elimination of up to $100 \%$ of the phytoplankton standing stock (Lopez and Anadon, 2008).

The flexibility and switches in feeding strategy of copepods in coastal subtropical communities also means that coupling in the abundance of phytoplankton and herbivorous zooplankton might occur temporarily, during a certain period of time, the duration of which is unknown. As for the whole time series covering the range from 2007 to 2011, a comparison of the total copepod and the phytoplankton group abundance enabled us to denote no general concordance in timing of the abundance peaks. In $64 \%$ of cases, the copepod peaks were lagging the diatom or dinoflagellate peaks, by one or two months.

There are a number of other ecologically important factors mediating monthly changes of copepod populations. For instance, algal toxic blooms could suppress the abundance and occurrence of coastal copepod species (Lester et al., 2008). In our case, the harmful algal bloom of dinoflagellate Cochlodinium polykrikoides in 2008 was not fully covered by zooplankton sampling.

In the Arabian Sea, sardines are consumers of phytoand zooplankton (Prasad, 1953; Sekharan, 1966). We speculated that, through the trophic press in particular in the upper layers, sardines and the other small pelagic species impact zooplankton, making the multiple peak structure of zooplankton abundance more pronounced. However, the data represented by figures 1-7 and 8 enabled us to assume that monthly changes of the total copepod 
abundance (as well as some typical species) were less related to changes of sardine landings in comparison to the seasonality of phytoplankton (especially diatoms) which had better matched the seasonal pattern of sardines in the Muscat region. The gut content analysis of the sardines caught along the coast of the Sea of Oman (in the Muscat and Sohar regions) has indicated that about $62-68 \%$ is contributed by phytoplankton (Haleem et al., 2011).

\section{Conclusion}

Zooplankton communities of the shallow coastal waters of Oman are diverse by taxa. However, Copepoda are the most numerous zooplankton organisms. Within copepods, no dominant species were found; instead, a group of 15 species comprised about $80 \%$ of the total zooplankton abundance. Changes of copepod abundance do not have a pronounced seasonal pattern. On the level of genera and the abundant species, a multiple peak structure in monthly fluctuations was observed. Amplitudes and timing of the copepod peak abundance were markedly different during the studied years (2007-2011).

\section{Acknowledgments}

Samples were collected by S. Al-Khusaibi. Phytoplankton was processed to the species level by L. Manzhos and L. Kuzmenko. The work of these colleagues is greatly appreciated. This research was supported by the TRC grant \# ORG/EBR/09/04, the SQU grant IG/AGR/FISH/13/01, and the Ministry of Fisheries Wealth Fund.

\section{References}

Al-Gheilani, H.M., A.Y.A. Al-Kindi, S. Amer, and Y.K. Al-Akhzami. 2005. Harmful algal blooms: physiology, behavior, population dynamics and global impacts- a review. Sultan Qaboos University Journal of Sciences 10:1-30.

Al-Hashmi, K., Y.V.B. Sarma, M. Claereboudt, A.R. Al-Azri, S.A. Piontkovski, and H. Al-Habsi. 2012. Phytoplankton community structure in the Bay of Bandra Khyran, Sea of Oman with special reference to Harmful Algae. International Journal of Marine Science 2:24-35.

Al-Khabbaz, M. and A.M. Fahmi. 1998. Distribution of Copepoda in the ROPME Sea Area 1994. In: Offshore Environment of the ROPME Sea Area after the Warrelated Oil Spill, A. Otsuki et al. (Editors), 303-318. Terra Scientific Publishing Company, Tokyo.

Al-Yamani, F., K. Al-Rifaie, H. Al-Mutairi, and W. Ismail. 1998. Post-spill Spatial Distribution of Zooplankton in the ROPME Sea Area. In: Offshore Environment of the ROPME Sea Area after the War-related Oil Spill, A. Otsuki et al. (Editors), 193-202. Terra Scientific Publishing Company, Tokyo.

Anonymous. 1975. Reports on cruises Nos. 1 and 2 of R.V. "Dr. Fridtjof Nansen". Indian OceanFishery- and
Development Programme, Pelagic Fish Assessment Survey, North Arabian Sea, F.A.O. ROPME.

Baars, M.A. 1994. Monsoons and Pelagic Systems. National Museum of Natural History, Leiden.

Burkill, P. 1999. ARABESQUE: an overview. Deep-Sea Research II, 46:529-548.

Calbet, A., D. Atienza, C.H. Henriksen, E. Saiz, and T.R. Adey. 2009. Zooplankton grazing in the Atlantic Ocean: A latitudinal study. Deep-Sea Research II, 56:954-963.

Dam, H.G., C.A. Miller, and S.H. Jonasdottir. 1993. The trophic role of mesozooplankton at $47^{\circ} \mathrm{N}, 20^{\circ} \mathrm{W}$ during the North Atlantic Bloom Experiment. Deep-Sea Research II, 40:197-212.

Drits, A.V. and T.N. Semenova. 1984. Experimental investigations of the feeding of Oithona similis Claus. Oceanology 24:755-759.

Fazeli, N., H.R. Marnani, S. Sanjani, R. Zare, S. Dehghan, and N. Jahani. 2010. Seasonal variation of copepod in Chabahar Bay-Gulf of Oman. Jordan Journal of Biological Sciences 3:153-164.

Fishery Statistics Book. 2011. Ministry of Fisheries Wealth. Sultanate of Oman.

Fonda-Umani, S., V. Tirelli, A. Beran, and B. Guardiani. 2005. Relationships between microzooplankton and mesozooplankton: competition vs predation on natural assemblages in the Gulf of Trieste (northern Adriatic Sea). Journal of Plankton Research 27:973-986.

Gallienne, C.P. and D.B. Robins. 2001. Is Oithona the most important copepod in the world's oceans? Journal of Plankton Research 23:1421-1432.

George, G., B. Meenakumari, M. Raman, S. Kumar, P. Vethamony, M. Babu, and X. Verlecar, 2012. Remotely sensed chlorophyll: a putative trophic link for explaining variability in Indian oil sardine stocks. Journal of Coastal Research 28:105-113.

Go, Y.B., B.C. Oh, and Y.C. Choi. 1996. Bioecological studies in the upwelling area of Cheju Island: Standing stock and distribution of pelagic zooplankton. Journal of the Korean Fisheries Society 29:271-278.

Haleem S.Z.A., N. Jayabalan, F. Al-Kiyumi, L. AlKharusi, S. Al-Habsi, and A. Al-Marzouqi. 2011. Fishery, biology and population dynamics of three small pelagic fish species (Indian oil sardine Sardinella longiceps, Indian mackerel Rastrelliger kanagurta and Indian scad Decapterus russeli) from the Sultanate of Oman. Project Final Report. Part II. Marine Science and Fisheries Center. Ministry of Agriculture and Fisheries Wealth. Muscat.

Jakobsen, H.H. 2005. Effects of prey motility and concentration on feeding in Acartia tonsa and Temora longicornis: the importance of feeding modes. Journal of Plankton Research 27:775-785.

Jayalakshmy, K.V. 2000. Spatial zonation of zooplankton in the Northwestern Arabian Sea: a multivariate approach. International Journal of Ecology and Environmental Sciences 26:253-268. 
Hitchcock, G.L., P. Lane, S. Smith, J. Luoa, and P.B. Ortner. 2002. Zooplankton spatial distributions in coastal waters of the northern Arabian Sea, August, 1995. Deep-Sea Research II, 49:2403-2423.

Hopkins, T.L. 1987. Midwater food web in McMurdo Sound, Ross Sea. Marine Biology 96:93-106.

Katechakis, A. and H. Stibor, H. 2004. Feeding selectivities on the marine cladocerans Penilia avirostris, Podon intermedius, and Evadne normanni. Marine Biology 145:529-539.

Kidwai, S. and S. Amjad. 2000. Zooplankton: presouthwest and northeast monsoons of 1993 to 1994, from the North Arabian Sea. Marine Biology 136: 561-572.

Lampitt, R.S., K.F. Wishner, C.M. Turley, and M.V. Angel. 1993. Marine snow studies in the Northeast Atlantic Ocean: distribution, composition and role as a food source for migrating plankton. Marine Biology 116:689-702.

Lester, K., C.A. Heil, M.B. Neely, D.N. Spence, S. Murasko, T.L. Hopkins, T.T. Sutton, S.E. Burghart, R.N. Bohrer, A.W. Remsen, G.A. Vargo, and J.J. Walsh. 2008. Zooplankton and Karenia brevis in the Gulf of Mexico. Continental Shelf Research 28:99111.

Lipej, L., P. Mozetic, V. Turk, and A. Malej. 1997. The trophic role of the marine cladoceran Penilia avirostris in the Gulf of Trieste. Hydrobiologia 360:197-203.

Longhurst, A.R. and W.S. Wooster. 1990. Abundance of oil Sardine (Sardinella longiceps) and upwelling on the southwest coast of India. Canadian Journal of Fisheries and Aquatic Sciences 47:2407-2419.

Lopez, E. and R. Anadon. 2008. Copepod communities along an Atlantic Meridional Transect: Abundance, size structure, and grazing rates. Deep-Sea Research 55:1375-1391.

Madhupratap, M., P. Haridas, N. Ramaiah, and C. Achuthankutt. 1992. Zooplankton of the southwest coast of India: abundance, composition, temporal and spatial variability in 1987. In: Oceanography of the Indian Ocean, B. Desai (Editor), 99-112. Oxford and IBH Publishing Co. Ltd, New Delhi.

Madhupratap, M., T.C. Gopalakrishnan, P. Haridas, K.K.C. Nair, P.N. Aravindakshan, G. Padmavati, and S. Paul. 1996. Lack of seasonal and geographic variation in mesozooplankton biomass in the Arabian Sea and its structure in the mixed layer Current Science 71:863-868.

Martynova, D.M., N.A. Kazus, U.V. Bathmann, M. Graeve, and A.A. Sukhotin. 2011. Seasonal abundance and feeding patterns of copepods Temora longicornis, Centropages hamatus and Acartia spp. in the White Sea $\left(66^{\circ} \mathrm{N}\right)$. Polar Biology 34:1175-1195.

Matsuoka, K., Y. Takano, E. Kamrani, H. Rezai, S.T. Puthiyedathu, and H.M. Al Gheilani. 2011. Study on Cochlodinium polykrikoides Margalef (Gymnodiniales, Dinophyceae) in the Oman Sea and the Persian Gulf from
August 2008 to August 2009. Current Development in Oceanography 1:153-171.

Nishibe, Y., T. Kobari, and T. Ota. 2010. Feeding by the cyclopoid copepod Oithona similis on the microplankton assemblage in the Oyashio region during spring. Plankton and Benthos Research 5:74-78.

Ohtsuka, S., R. Böttger-Schnack, M. Okada, and T. Onbé. 1996. In situ feeding habits of Oncaea (Copepoda: Poecilostomatoida) from the upper $250 \mathrm{~m}$ of the central Red Sea, with special reference to consumption of appendicularian houses. Bulletin of the Plankton Society of Japan 43:89-105.

Paffenhofer, G.A. and J.D. Orcutt. 1986. Feeding, growth and food conversion of the marine cladoceran Penilia avirostris. Journal of Plankton Research 8:741-754.

Paffenhöfer, G.A. 1993. On the ecology of marine cyclopoid copepods (Crustacea, Copepoda). Journal of Plankton Research 15:37-55.

Panikkar, N.K. and T.S.S. Rao. 1973. Zooplankton investigations in Indian waters and the role of the Indian Ocean Biological Centre. Handbook to the International Zooplankton Collections 5:111-162

Pasternak, A.F. 1984. Feeding of copepods of the genus Oncaea (Cyclopoida) in the southeastern Pacific Ocean. Oceanology 24:609-612.

Poulsen, L.K. and T. Kiørboe, T. 2005. Coprophagy and coprorhexy in the copepods Acartia tonsa and Temora longicornis: clearance rates and feeding behavior. Marine Ecology Progress Series 299:217-227.

Prasad, R.P. 1953. Swarming of Noctiluca in the Palk Bay and its effect on the "Choodai" fishery with a note on the possible use of Noctiluca as an indicator species. Proceedings of the Indian Academy of Sciences B, 38: 40-47.

Richlen, M.L., S.L. Morton, E.A. Jamali, A. Rajan, and D.M. Anderson. 2010. The catastrophic 2008-2009 red tide in the Arabian Gulf region, with observations on the identification and phylogeny of the fish-killing dinoflagellate Cochlodinium polykrikoides. Harmful Algae 9:163-172.

Roman, M., S. Smith, K. Wishner, X. Zhang, and M. Gowing. 2000. Mesoplankton production and grazing in the Arabian Sea. Deep-Sea Research II, 47:1423-1450.

Sekharan, K.V. 1966. On the food of the sardines, Sardinella albella (VAL.) and S.gibbosa (BLEEK.) of the Mandapam area. Indian Journal of Fisheries 13:96-141.

Smith, S.L. and M. Madhupratap. 2005. Mesozooplankton of the Arabian Sea: Patterns influenced by seasons, upwelling, and oxygen concentrations. Progress in Oceanography 65: 214-239.

Smith, S. L., L.A. Codispoti, J.M. Morrison, and R.T. Barber. 1998a. The 1994-1995 Arabian Sea Expedition: an integrated,interdisciplinary investigation of the response of the northwestern Indian Ocean to monsoonal forcing. Deep-Sea Research II, 45:1905-1916.

Smith, S., M. Roman, I. Prusova, K. Wishner, M. Gowing, L. Codispoti, et al. 1998b. Seasonal response of 
zooplankton to monsoonal reversals in the Arabian Sea. Deep-Sea Research II, 45:2369-2403.

Tangaraja, M., A. Al-Aisry, and L. Al-Kharusi, L. 1997. Harmful algal blooms and their impacts in the middle and outer ROPME sea area. International Journal of Oceans and Oceanography 2:85-98.

Timonin, A.G.1971. The structure of plankton communities of the Indian Ocean. Marine Biology 9:281-289.

Turner, J.T. 1986. Zooplankton feeding ecology: contents of fecal pellets of the cyclopoid copepods Oncaea venusta, Corycaeus amazonicus, Oithona plumifera, and O.simplex from the northern Gulf of Mexico. P.S.Z.N.I. Marine Ecology 7:289-302.

Turner, J.T. P.A. Tester, and R.L. Ferguson. 1988. The marine cladoceran Penilia avirostris and the "microbial loop" of pelagic food webs. Limnology and Oceanography 33:245-255.

Uchima, M. and R. Hirano. 1986. Food of Oithona davisae (Copepoda: Cyclopoida) and the effect of food concentration at first feeding on the larval growth. Bulletin of the Plankton Society of Japan 33:21-28.

Yule, A.B. and D.J. Crisp. 1983. A study of feeding behaviour in Temora longicornis Müller (Crustacea: Copepoda). Journal of Experimental Marine Biology and Ecology 71:271-282.

Wu, C-H., J-S Hwang, and J-S Yang. 2004. Diets of three copepods (Poecilostomatoida) in the Southern Taiwan Strait. Zoological Studies 43:388-392.

Received: March 11, 2013

Accepted: May 28, 2013 